
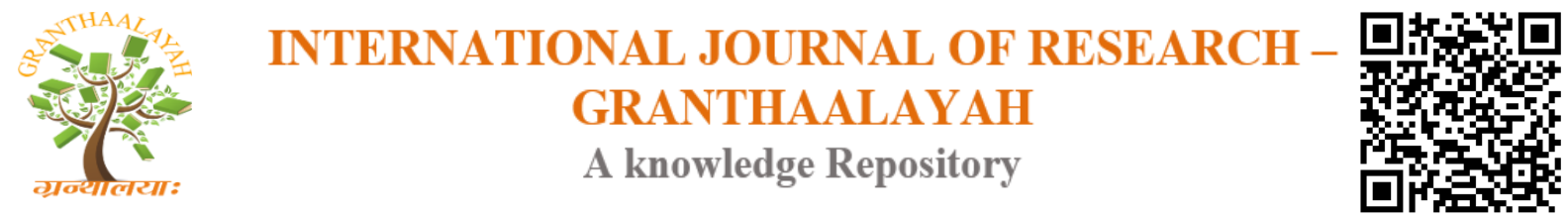

Management

\title{
MOTIVES FOR SELECTING HOUSEKEEPING DEPARTMENT AS A CAREER-A STUDY OF SELECTED HOTELS OF NORTH INDIA
}

\author{
Dr. Dilbag Singh ${ }^{* 1}$, Mr. Amandeep ${ }^{2}$ \\ ${ }^{* 1}$ Assistant Professor, Department of Tourism and Hotel Management, Central University of \\ Haryana, India \\ ${ }^{2}$ Assistant Professor, Department of Tourism and Hotel Management, Central University of \\ Haryana, India
}

\begin{abstract}
Hotel Industry around the world is a marginal revenue generator which provides comfortable and luxurious services from lodging, food, entertainment, business and leisure needs to the individuals at any given moment. Out of all the departments which run the hotels, Housekeeping has been always stayed back of the house and performed to its never ending duties $24 \times 7 \times 365$ in pursuit of providing clean, hygienic, fresh environment and comfort to every individual stepping into the hotel. A hotel may be a budget or a 5 star categorized one but nothing sends a stronger message than cleanliness in a hospitality operation and that's always maintained by the housekeeping department. Like any other department housekeeping also offers and individual to make a successful career and achieve different heights in the management up to the level of General Manager. As the job opportunities increases in hotels, and housekeeping department being the largest employer alone department wise as stated in a report by National Skill Development Corporation 2012, it is definitely a great time for employees who wish to advance their career or choose housekeeping as their career choice.

The purpose of this paper is to examine the motives and factors that influence the employee engagement in housekeeping department. Four independent variables have been identified as the factors that are going to be tested in this research which will provide us with essential data on different motives.
\end{abstract}

Keywords: Housekeeping; Motives; North India.

Cite This Article: Dr. Dilbag Singh, and Mr. Amandeep. (2017). "MOTIVES FOR SELECTING HOUSEKEEPING DEPARTMENT AS A CAREER- A STUDY OF SELECTED HOTELS OF NORTH INDIA." International Journal of Research - Granthaalayah, 5(7), 309-314. https://doi.org/10.29121/granthaalayah.v5.i7.2017.2137.

\section{Introduction}

Hotels in India are growing much faster than ever before. With under the pipeline hotels from international chains to the hundreds of budget hotels and service apartments across the country, 
all categories of the hotel industry is rapidly growing in number. This obviously is the result of flourishing returns and expected room inventories which are being projected by many renowned survey companies and the government reports such as the Deloitte, HVS, NSDC and a lot more. India has been also ranked 8th out of 185 countries in the long term growth forecast from 2017 2027 by World Travel and Tourism Council, Economic impact report 2017 India As a result the industry also opens up employment opportunities to the people who want to make their future in the hotel industry. Need of specialized staff for each department of hotel such as Front Office, Housekeeping, Production and Service will increase automatically. According to the National Skill Development Corporation Report the Housekeeping department of the hotel industry alone is estimated to be at $22.83 \%$ the highest among four by 2022 . Housekeeping today is no longer considered as the back of the house department and a lot of hotels are trying to make the housekeeping staff interact more and more with the guest so as to know their requirements and provide better services. Housekeeping department is the one which maintain the perishable and most important product for revenue the room inventory which alone contributes minimum of $50 \%$ revenue generated by hotels. In view of the available data and facts it becomes an interesting task to find out the motives and interests for selecting Housekeeping department as a career by a possible professional employee. This paper is an attempt to find out the various reasons and motives for an individual who would like to join housekeeping for his career and how the findings of this can help the potential future employees to decide their interest. A Questionnaire was designed with various parameters to record the inputs which was then distributed in various hotels of north India for data collection.

\section{Literature Review}

Employees are the backbone for any of the organization hotel industry is not an exception. The success or failure of any of the organization is directly related to the satisfaction level of the employees working with the organization. During a financial year a hotel spends a lot for the re recruitment of the employees, which is very serious. So it is very much important to know the various motives of selection housekeeping as a career. A number of discussions have been made on the relationship between the various that affects the motivation of the employee towards housekeeping department in Hotel Industry. Lindner (1998) states in his study that good working conditions, being praised, promotion opportunities, and the relation of senior staff with the operational staff directly related to the motivation to work with a department. Nelson (1996) writes that according to the managerial level appreciation and reward for the performances are some of the motivations which increase the bonding of the staff with the organization. Olcer (2005) states that employee satisfaction, job security, good relation with supervisor, reward for good work, cooperative working environment increase the level of motivation to work in the organization for a long time. Orucu and Esenkal (2005) try to find out in their study the relation of motives with the family relations and the job commitment. Wong and Pang (2003) states in their study that training program and motivation from the top management are the most effective tools to boost the motives of the employees to work in service sectors like hotel industry. Aksu (2005) writes in his study that before starting any of the training program motivation is the most effective factor which increases the level of satisfaction in the employees and boost the motive to stay with the organization. Das and Baruah (2013) find in their study that rewards for good work is the most effective tool to motivate the employees apart from that use of reasonable and flexible work shifts are also one of the effective tools for motivation, with the help of motivation 
strategies an organization can enhance the motives of employees to stay in the organization and also attracts the new employees towards the organization. Poulston (2008) states in his study that the supervisors play an important role in good working environment building, they should recognize the skill and contribution of the subordinates time to time. In this way the employees feel satisfied and suppose him to stay in the same organization for a long time. Jones and Lockwood (2002) write in their study that flexibility of employees can be increased by moving them in other departments also as required, it increase the level of interdepartmental coordination and make the employees more satisfied. Parsuraman (2001) state in his study that work life balance is one of the most important key to employee satisfaction, if the employee are unable to balance the work life and personal life it will enhance the level of dissatisfaction. Jones (2002) highlights in his study that proper briefing of the staff hsve the biggest impact of retention of staff for a long time because briefing is a effective tool to communicate with the employees on daily basis. It also helps to solve the minor issues of the employees and helps to increase the level of the satisfaction between the employees. Walker (2001) suggests for the employee retention appreciation of performed work, provision of challenging work, chance of promotion, healthy work environment, good relations with colleagues, Balance in work and personal life are some of the factors.

\section{Objective of the Study}

The objective of the study is to find out the various motives of joining the housekeeping department as a career.

\section{Research Design and Methodology of the Study}

The research design and methodology for the study was not an easy task so these were discuss on the prior stage with the expert in the relevant field, the housekeeping managers and the personal from Operational Staff in the hotel housekeeping department too. The purpose of the study was to find out the motives of joining the housekeeping department in the hotel industry. A structured questionnaire was developed to know the various motives of joining the housekeeping department in hotel industry; the research was done to understand the various motives of joining the housekeeping department in North India.

Table 1: Demographic Profile of the Respondents

\begin{tabular}{|l|l|l|l|}
\hline & & Frequency & Valid Percentage \\
\hline \multirow{5}{*}{ Type of Hotel } & 5 Star & 150 & 33.3 \\
\cline { 2 - 4 } & 3 Star & 150 & 33.3 \\
\cline { 2 - 4 } & Budget & 150 & 33.3 \\
\hline \multirow{5}{*}{ State } & Delhi & 90 & 20.0 \\
\cline { 2 - 4 } & Haryana & 90 & 20.0 \\
\cline { 2 - 4 } & Punjab & 90 & 20.0 \\
\cline { 2 - 4 } & Himachal Pradesh & 90 & 20.0 \\
\cline { 2 - 4 } & Rajsthan & 90 & 20.0 \\
\hline \multirow{4}{*}{ Age } & Below 20 & 43 & $\mathbf{4 0 . 0}$ \\
\cline { 2 - 4 } & $21-30$ & 180 & $\mathbf{3 8 . 4}$ \\
\cline { 2 - 4 } & $31-40$ & 173 & \\
\hline
\end{tabular}




\begin{tabular}{|c|c|c|c|}
\hline & $41-50$ & 45 & 10.0 \\
\hline & 51 and Above & 9 & 2.0 \\
\hline \multirow[t]{3}{*}{ Education } & $10+2$ & 222 & 49.3 \\
\hline & Graduation & 162 & 36.0 \\
\hline & Post Graduation & 66 & 14.7 \\
\hline \multirow[t]{2}{*}{ Gender } & Male & 416 & 92.4 \\
\hline & Female & 34 & 7.6 \\
\hline \multirow[t]{3}{*}{$\begin{array}{l}\text { Your position in } \\
\text { Housekeeping } \\
\text { Department }\end{array}$} & $\begin{array}{l}\text { Executive } \\
\text { Housekeeper/Deputy } \\
\text { Housekeeper. }\end{array}$ & 75 & 16.7 \\
\hline & Housekeeping Supervisor. & 150 & 33.3 \\
\hline & Room Attendant & 225 & 50.0 \\
\hline
\end{tabular}

The current table shows the distribution of demographic profile of the employees working in the hotels in North India. In the survey 33.3\% employees were from 5 star hotels, $33.3 \%$ were from 3 Star hotels and $33.3 \%$ were from budget segment of hotels. Five states were covered from North India, 20\% of employees were from Delhi 20\% from Haryana 20\% were from Punjab 20\% were from Himachal Pradesh and 20\% were from Rajasthan. As per the age group the majority of employees $40.0 \%$ were from the age group of $21-30$ years, $38.4 \%$ of employees $31-40,10.0 \%$ were from the age group of 41-50 years, 9.6\% of employees were below 20 years and the least $2.0 \%$ were from the age group of more than 50 years. According to their qualification majority of the employees $49.3 \%$ were $10+2$, graduate employees were $36.0 \%$ and the rest $14.7 \%$ were having post graduate degree. As per the gender $92.4 \%$ of employees were male and the $7.6 \%$ of employees were female. According to the hierarchy of housekeeping department three levels of employees were considered namely these were executive housekeeper, housekeeping supervisor and room attendants the said executive housekeepers were $16.7 \%$ of total employees, the supervisors were $33.3 \%$ and the room attendants were $50.0 \%$.

\section{Research Findings}

Based on secondary data, a number of motives for selecting housekeeping department were identified. The analysis is presented in table 2. Respondents were asked questions on 5 point likert scale. Factor analysis method is used to reduce these variables to limited number of factors. The analysis is done with the help of principal component analysis and varimax rotation matrix. 24 variables were identified based upon secondary researches for hotel preferences. The output of principal component analysis shows Eigen value of nine factors are more than 1 explaining $78.85 \%$ percent of total variance thus reducing 16 variables to underlying 4 factors.

Table 2: Rotated Component Matrix

\begin{tabular}{|l|l|l|l|l|}
\hline Rotated Component Matrix $^{\text {a }}$ & Component & \\
\hline $\begin{array}{l}\text { I joined the housekeeping } \\
\text { department because of: }\end{array}$ & 1 & 2 & 3 & 4 \\
\hline Mechanized Work & .811. & & & \\
\hline Job Availability & .801. & & & \\
\hline
\end{tabular}




\begin{tabular}{|l|l|l|l|l|}
\hline Better Personal Relations & .799 & & & \\
\hline Less Training Required & .734 & & & \\
\hline Quick Promotions & .607 & & & \\
\hline Healthy Work Environment & & .854 & & \\
\hline Flexible Work Shifts & & .842 & & \\
\hline Low Level of Stress & & .621 & & \\
\hline Better Uniforms & & .571 & & \\
\hline Less Interaction With Guest & & & .808 & \\
\hline Low Work Pressure & & & .706 & \\
\hline Low Risk & & & .584 & \\
\hline Suggested By Friend & & & .441 & .340 \\
\hline Hotel Related Family Background & & & & .733 \\
\hline Only Job Available & & & &. .648 \\
\hline Personal Interest & & & & \\
\hline
\end{tabular}

Factor1: Five variables are loaded in this factor these are Mechanized Work .811, Job Availability .801, Better Personal Relations .799, Less Training Required .734, Quick Promotions .607

Factor2: Four variables are loaded in this factor these are Healthy Work Environment.854, Flexible Work Shifts.842, Low Level of Stress.621, and Better Uniforms.571

Factor3: Five variables are loaded in this factor these are Less Interaction with Guest.808, Low Work Pressure.706, Low Risk.584, and Suggested by Friend.441, Hotel Related Family Background.340

Factor4: Two variables are loaded in this factor these are Only Job Available.733, Personal Interest. 648

\section{Conclusion}

Hospitality Industry compromises of many areas and work aspects which are very complex in nature, so it is a very difficult task to understand what exactly the employees are thinking about the industry and what are the different types of motives which works while selecting housekeeping department as a career. Finally it is envisaged that the study leads to increase the awareness about the employees of Indian hotel industry, and their opinion about the motives of joining the housekeeping department in hotel industry. From the study four clusters of motives have emerged from the study which is shown in the finding part. Though, the present study is just confined to the selected hotels of North India but still it can be helpful for the scholars \& researchers, who are doing research in related field by applying the same in bigger area. The researcher can inculcate wide range of variables related to reasons of employee turnover and do the potential research.

\section{References}

[1] Das, B. and Baruah, M. (2013) "Employee Retention: A Review of Literature". Journal of Business and Management 14 (2): pp 8-16 (Online) Available from: http://iosrjournals.org/iosrjbm/papers/Vol14-issue2/B01420816.pdf 
[2] Jones, P. and Lockwood, A., (2002), the Management of Hotel Operations. London: Cengage Learning.

[3] Linder, J.R. (1998). Understanding Employee Motivation. Journal of Extension, 36(3):28-43.

[4] Nelson, B. (1996). Dump the Cash, Load on The Praise. Personnel Journal, 75 (7): 65-70.

[5] Alain Cohn, Michel André Maréchal(2015),Job History, Work Attitude, and Employability, Technical Report.

[6] Yijing Lyu, Xing Zhou, Weiwen Li (2016), The impact of abusive supervision on service employees' proactive customer service performance in the hotel industry, International Journal of Contemporary Hospitality Management.

[7] Richard N. S. Robinson, Anna Kralj, Solnet David, Victor J. Callan (2016), Attitudinal similarities and differences of hotel frontline occupations, International Journal of Contemporary Hospitality Management 28(5):1051-1072.

[8] Parasuraman, S. and Simmers, C.A. (2001), "Type of employment, work-family conflict and Well- being: a comparative study", Journal of Organizational Behaviour, 22, pp. 551-68.

[9] Poulston, J. (2008) 'Hospitality Workplace Problems and Poor Training: A Close Relationship', International Journal of Contemporary Hospitality Management, 20(4):pp.412-427

[10] Walker, J.W. (2001). "Perspectives" Human resource planning. 24 (1):pp. 6-10

[11] Wong, S., \& Pang, L. (2003). Motivators to creativity in the hotel industry perspectives of managers and supervisors. Tourism management, 24: 551-559.

[12] National Skill development Corporation, Human Resource and skill requirement in hotel industry, Study on mapping human resource skill gaps in India till 2022.

[13] World Travel and Tourism Council, Economic impact report 2017 India.

[14] Ning Kuang Chuang, Mary Dellmann-Jenkins (2010) Career Decision Making and Intention: a Study of Hospitality Undergraduate Students, Journal of Hospitality \& Tourism Research 34(4):512-530

*Corresponding author.

E-mail address: dilbagsingh@ cuh.ac.in 